\title{
DECARBONISATION OF THE STEEL INDUSTRY - PATHWAY TO BRIGHTER FUTURE - SLOVAKIA AND CZECH REPUBLIC CASE STUDY
}

\author{
'Slavomír HUBATKA, 'Branislav BUL'KO, '2Dana BARICOVÁ, ${ }^{1}$ Peter DEMETER, \\ ${ }^{1}$ Lukáš FOGARAŠ, ${ }^{1}$ Vladimír ŠABÍK \\ ${ }^{1}$ TUKE - Technical University of Košice, Košice, Slovakia, EU, slavomir.hubatka@tuke.sk \\ ${ }^{2}$ Výskumno-inovačné a technologické centrum,n.o., Košice, Slovakia, EU, dana.baricova@vtp.sk
}

https://doi.org/10.37904/metal.2021.4300

\begin{abstract}
The aim of this study is to analyze the potential of decarbonization of steel production in Slovakia and Czech Republic. The study examines the European $\mathrm{CO}_{2}$ emissions policy, steel production trends, and the European emission trading system (EU ETS) allowances and emissions of Slovakia and Czech Republic steel producers. The production of iron, steel and non-ferrous metals has a significant presence in Slovakia and Czech Republic. The metal industry, mainly iron and steel, is one of the largest energy-consuming industry, followed by non-metallic minerals. Steel making ranks as one of the three highest $\mathrm{CO}_{2}$ emitting industries, and since production occurs in a limited number of locations - the U.S. Steel Košice, s. r. o. steel-mill being the largest single producer of emissions in Slovakia and Třinecké Železárny, a. s. with Liberty Ostrava, a. s. being ones of the largest in Czech Republic - they are prime candidates for decarbonization. This paper deals with the analysis of the metallurgical sector of steel production in Slovakia and the Czech Republic using the European Union Emission Trading Scheme (EU ETS).
\end{abstract}

Keywords: decarbonization, metallurgy, emissions, EU ETS, green steel

\section{INTRODUCTION}

On the one hand, an ambitious European Climate Action Program to 2020 must be seen as a huge success, and on the other, real work is just beginning five years after the Paris Agreement, all 27 Member States of the European Union (EU) have agreed on an ambitious medium-term plan to reduce emissions by at least $55 \%$ by 2030 compared to 1990, a proposal adopted by the European Council in December 2020 [1,2,3]. The European Union Emission Trading Scheme (EU ETS) is the primary tool for Slovakia and the Czech Republic in setting carbon prices and is also a central policy tool for reducing greenhouse gas emissions [4]. The EU ETS is a cornerstone of the European Union's policy to combat climate change and is a key tool for reducing greenhouse gas emissions cost-effectively, covering around $40 \%$ of all greenhouse gas emissions in the European Union. The EU ETS operates on a "cap and trade" basis. A ceiling is set for the total amount of certain greenhouse gases that may be emitted by installations covered by this scheme. The limit decreases over time, so total emissions decrease [4].

The largest emitters of greenhouse gases in the European Union are the energy industry, fuel combustion and transport. Industrial processes produce only $8.7 \%$ of emissions within the Union as shown in Figure 1. The production of key materials and chemicals - steel, plastics, ammonia, and cement - emits approximately 500 million tons of $\mathrm{CO}_{2}$ per year, $14 \%$ of the EU total. The greenhouse gas of most relevance to the world steel industry is carbon dioxide $\left(\mathrm{CO}_{2}\right)$. On average, 1.9 tons of $\mathrm{CO}_{2}$ are emitted for every ton of steel produced. According to the International Energy Agency, the iron and steel industry accounts for approximately $4-5 \%$ of 
total world $\mathrm{CO}_{2}$ emissions. The European steel industry produces 169 million tons of steel per year as shown in Figure 2 which stands for only $8,4 \%$ of 2019 worldwide steel production $[5,6,7,8]$.

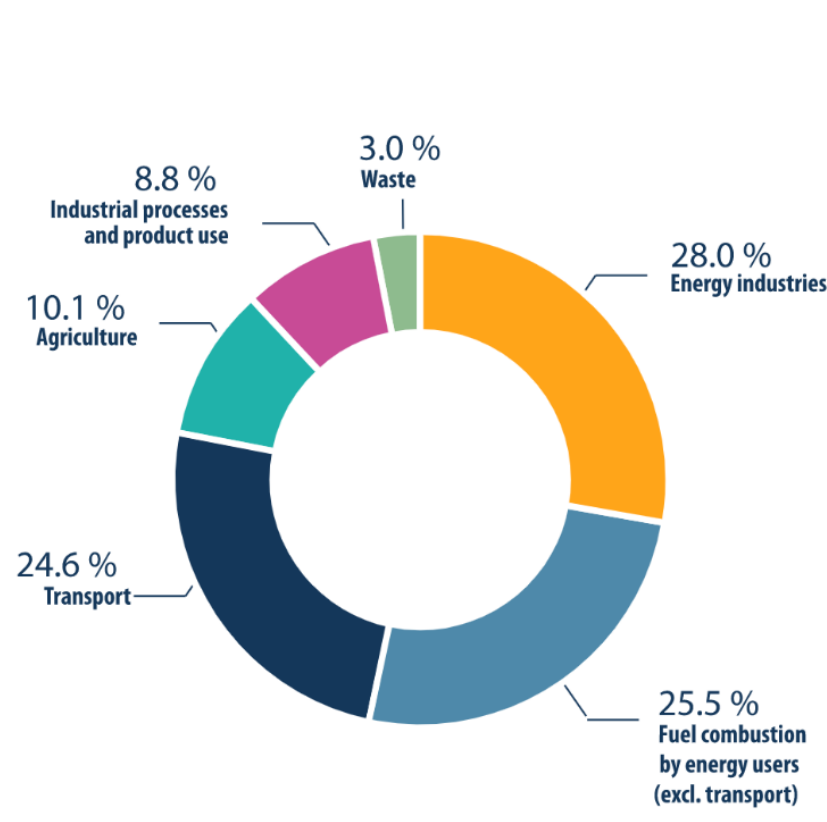

Figure 1 EU sectoral greenhouse gas emission production [6]

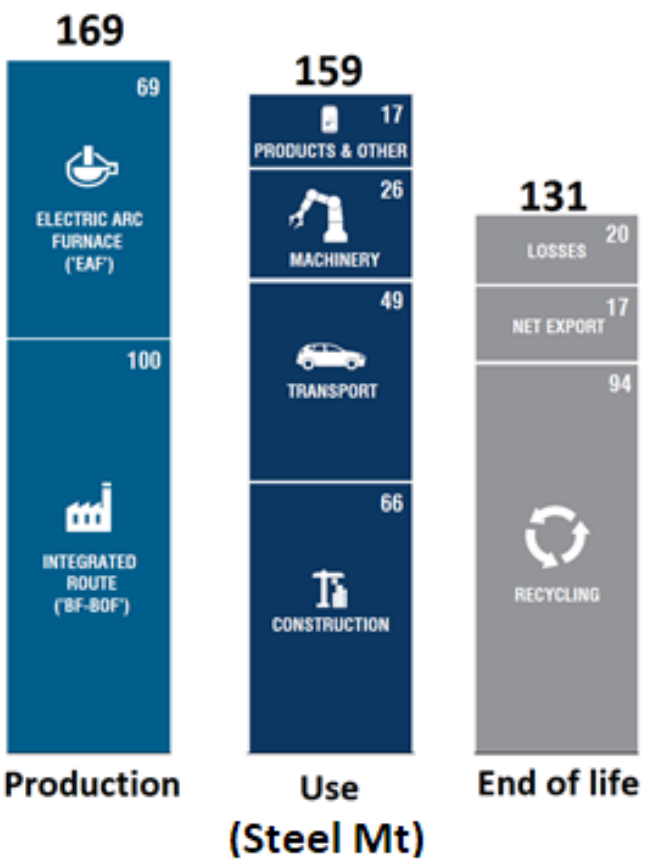

Figure 2 Production, use, and end of life OF EU steel (Annual steel production Mt, 2017) [8]

The current trend in metallurgy is to achieve the production of high-quality and competitive steel on the world market with the lowest possible amount of $\mathrm{CO}_{2}$ emissions per ton of steel produced. The increasing demand for quality steel on the world market is putting pressure on innovation and optimization of current technologies and the implementation of new processes in the metallurgical industry in order to achieve carbon neutrality.

\section{RESEARCH FINDINGS}

Slovakia produced 36,09 Mt and the Czech Republic produced 104,41 Mt of $\mathrm{CO}_{2}$ emissions in year 2018 $[9,10]$. The Slovak steel production company U. S. Steel Košice, s. r. o. in year 2018 produced $9.3 \mathrm{Mt}$ of $\mathrm{CO}_{2}$ emissions, which makes up $25.77 \%$ of the total amount of emissions produced in Slovakia. In the case of the Czech Republic, the steel production company Třinecké Železárny, a. s. produced $4.3 \mathrm{Mt}$ of $\mathrm{CO}_{2}$ emissions in 2018 and Liberty Ostrava, a. s. produced $5.3 \mathrm{Mt}$ of $\mathrm{CO}_{2}$, which represents $4.15 \%$ and $5.11 \%$, respectively. The steel production capacity of individual companies is as follows: U. S. Steel Košice, s. r. 0. $4.5 \mathrm{Mt}$, Třinecké Železárny, a. s. 2.6 Mt and Liberty Ostrava, a. s. 3.6 Mt.

The production of $\mathrm{CO}_{2}$ emissions in selected integrated steel plants was based on the European ETS trading system from 2010 including the prediction for 2030 as shown in Table 1. Predicted data for individual companies until 2030 were based on public statements of each individual steel producer with the assumption for continuous reduction of emissions until year 2030 without a significant change in the process and technologies used over the next 10 years. New measures and innovations of existing equipment will be introduced for each individual producers with the aim of reducing the amount of $\mathrm{CO}_{2}$ emissions without the need to change their overall technological process. Due to the high initial investment costs and the timeconsuming implementation of innovations in Integrated steel production, the transition to zero-emission steel in selected companies is expected beyond 2030. Potential interventions in the production cycle in the form of production limitation are not included in the prediction data. The forecast is informative and creates a picture 
of the potential emissions costs of individual companies in the optimistic scenario of the development of the price of emission allowances as shown in Figure 3. Companies can get part of their quotas free of charge, the rest they must buy at auction or at the market. Each quota represents the right to emit one ton of carbon dioxide $\left(\mathrm{CO}_{2}\right)$. The total costs associated with the purchase of emission allowances are based on the principle of the difference between Free Allocation and Verified emissions, the difference being the company's loss or profit.

The European Commission is due to propose its Carbon Border Adjustment Mechanism (CBAM) on July 14, 2021, a move designed to put EU firms on an equal footing with competitors in countries with weaker carbon policies [11]. The European Parliament has already expressed its views on CBAM, saying free allowances must continue. In fact, a phase-in and phase-out period can be envisaged where both systems co-exist [12,13]. For this reason, two predictions of free allowances are given, with a year-on-year decrease of $2.5 \%$ and $10 \%$ by 2030 . A $2.5 \%$ reduction represents an ambitious plan to reduce emissions by $55 \%$ by 2030 and a $10 \%$ reduction represents a potential transition period for CBAM. The analysis of the price of emission allowances of individual steel companies is shown in Figures 4,5,6.

Table 1 Analysis of emission quotas of steel mills - U. S. Steel Košice, s. r. o. Slovakia, Třinecké Železárny, a. s. and Liberty Ostrava, a. s. Czech Republic

\begin{tabular}{|c|c|c|c|c|c|c|c|c|c|}
\hline \multirow[b]{3}{*}{ Year } & \multicolumn{9}{|c|}{ Steel company } \\
\hline & \multicolumn{3}{|c|}{ U.S. Steel Košice - Slovakia } & \multicolumn{3}{|c|}{ Třinecké železárny - Czech Republic } & \multicolumn{3}{|c|}{ Liberty Ostrava - Czech Republic } \\
\hline & $\begin{array}{l}\text { Verified } \\
\text { emissions } \\
\left(\mathrm{CO}_{2} \mathrm{Mt}\right)\end{array}$ & $\begin{array}{c}\text { Free } \\
\text { Allocation } \\
(- \\
2,5 \% \text { p.a. }) \\
\end{array}$ & $\begin{array}{c}\text { Free } \\
\text { Allocation } \\
(-10 \% \\
\text { p.a.) }\end{array}$ & $\begin{array}{c}\text { Verified } \\
\text { emissions } \\
\left(\mathrm{CO}_{2} \mathrm{Mt}\right)\end{array}$ & $\begin{array}{c}\text { Free } \\
\text { Allocation } \\
(-2,5 \% \\
\text { p.a.) }\end{array}$ & $\begin{array}{c}\text { Free } \\
\text { Allocation } \\
(-10 \% \\
\text { p.a.) }\end{array}$ & $\begin{array}{l}\text { Verified } \\
\text { emissions } \\
\left(\mathrm{CO}_{2} \mathrm{Mt}\right)\end{array}$ & $\begin{array}{c}\text { Free } \\
\text { Allocation } \\
\text { (-2,5\%p.a.) }\end{array}$ & $\begin{array}{l}\text { Free } \\
\text { Allocation } \\
(-10 \% \\
\text { p.a.) }\end{array}$ \\
\hline 2010 & 8445826 & \multicolumn{2}{|c|}{10793886} & 4606236 & \multicolumn{2}{|c|}{4396519} & 4977923 & \multicolumn{2}{|c|}{7067824} \\
\hline 2011 & 8493163 & \multicolumn{2}{|c|}{10793886} & 4434494 & \multicolumn{2}{|c|}{4756952} & 5153486 & \multicolumn{2}{|c|}{7067824} \\
\hline 2012 & 8812732 & \multicolumn{2}{|c|}{10793886} & 4413947 & \multicolumn{2}{|c|}{4756952} & 5135312 & \multicolumn{2}{|c|}{7067824} \\
\hline 2013 & 8397752 & \multicolumn{2}{|c|}{6416358} & 4613607 & \multicolumn{2}{|c|}{4412080} & 5323345 & \multicolumn{2}{|c|}{6066661} \\
\hline 2014 & 8962739 & \multicolumn{2}{|c|}{6304029} & 4527519 & \multicolumn{2}{|c|}{4280922} & 5387212 & \multicolumn{2}{|c|}{5815944} \\
\hline 2015 & 8646638 & \multicolumn{2}{|c|}{6190422} & 4398787 & \multicolumn{2}{|c|}{4164000} & 5108398 & \multicolumn{2}{|c|}{5564265} \\
\hline 2016 & 8867366 & \multicolumn{2}{|c|}{6075671} & 4437265 & \multicolumn{2}{|c|}{4027520} & 5678244 & \multicolumn{2}{|c|}{5311723} \\
\hline 2017 & 9172344 & \multicolumn{2}{|c|}{5959728} & 4262003 & \multicolumn{2}{|c|}{3891198} & 4861248 & \multicolumn{2}{|c|}{5058277} \\
\hline 2018 & 9279123 & \multicolumn{2}{|c|}{5842695} & 4332935 & \multicolumn{2}{|c|}{3731765} & 5332864 & \multicolumn{2}{|c|}{4804008} \\
\hline 2019 & 7474886 & 572 & 245 & 4272928 & 359 & 024 & 4448530 & 454 & \\
\hline & rediction of & $\mathrm{O}_{2}$ emission & (Verified Er & ssions) and & ocated allow & רces free of & arge (Free & ocation) 202 & 30 \\
\hline 2020 & 9179782 & 5605421 & 5605421 & 4220147 & 3461684 & 3461684 & 4367779 & 4293040 & 4293040 \\
\hline 2021 & 8946455 & 5465285 & 5073864 & 4167366 & 3375142 & 3115515 & 4287028 & 4185714 & 3863736 \\
\hline 2022 & 8713128 & 5328653 & 4513322 & 4114585 & 3290763 & 2769347 & 4206277 & 4081071 & 3434432 \\
\hline 2023 & 8479801 & 5195437 & 3952780 & 4061804 & 3208494 & 2423178 & 4125526 & 3979044 & 3005128 \\
\hline 2024 & 8246474 & 5065551 & 3392238 & 4009023 & 3128282 & 2077010 & 4044775 & 3879568 & 2575824 \\
\hline 2025 & 8013147 & 4938912 & 2831696 & 3956242 & 3050075 & 1730842 & 3964024 & 3782579 & 2146520 \\
\hline 2026 & 7779820 & 4815439 & 2271153 & 3903461 & 2973823 & 1384673 & 3883273 & 3688015 & 1717216 \\
\hline 2027 & 7546493 & 4695054 & 1710611 & 3850680 & 2899477 & 1038505 & 3802522 & 3595814 & 1287912 \\
\hline 2028 & 7313166 & 4577677 & 1150069 & 3797899 & 2826990 & 692336 & 3721771 & 3505919 & 858608 \\
\hline 2029 & 7079839 & 4463235 & 589527 & 3745118 & 2756316 & 346168 & 3641020 & 3418271 & 429304 \\
\hline 2030 & 6846512 & 4351654 & 0 & 3692337 & 2687408 & 0 & 3560269 & 3332814 & 0 \\
\hline
\end{tabular}




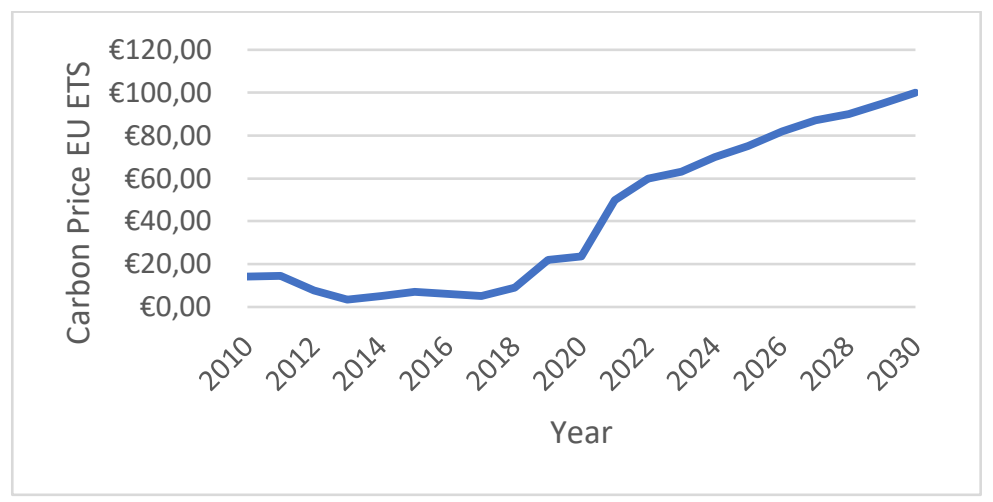

Figure 3 Carbon price prediction 2030

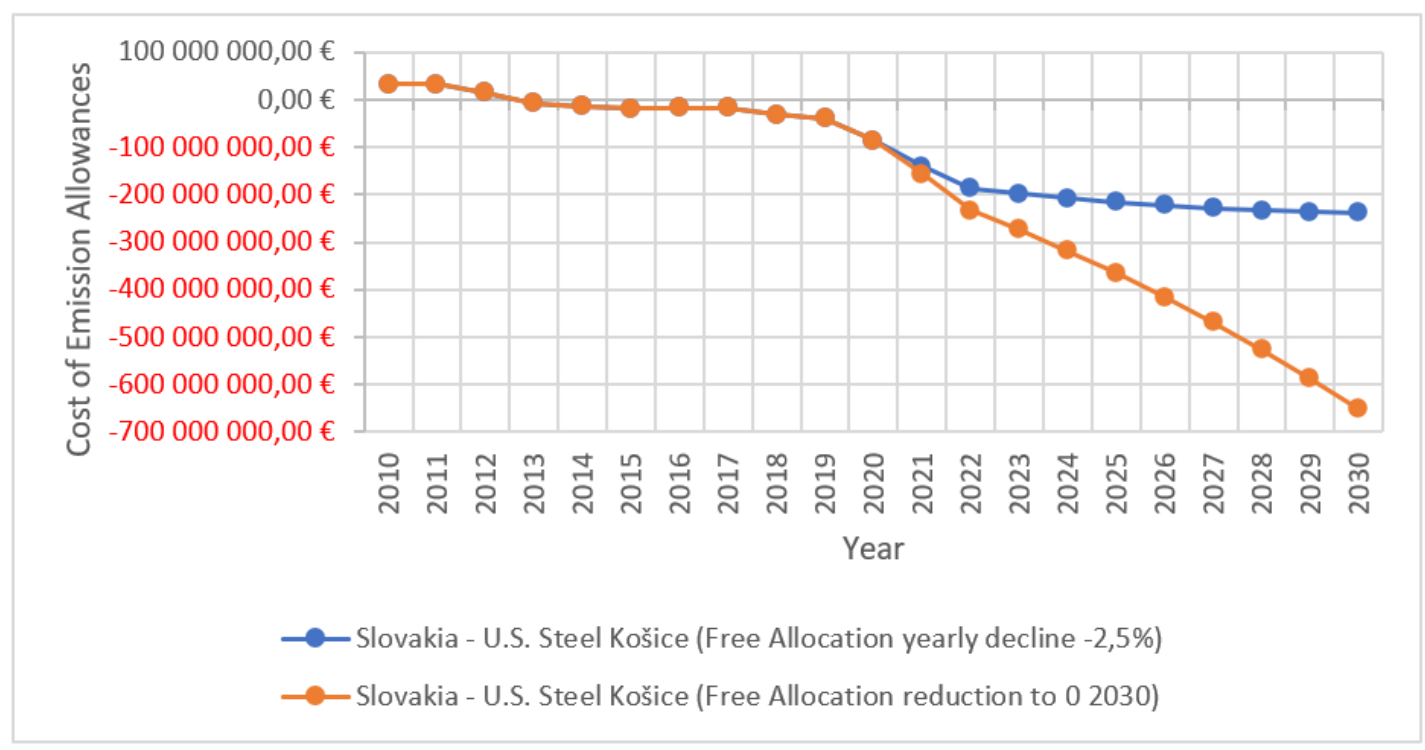

Figure 4 Price of emission allowances including prediction to 2030 - U. S. Steel Košice, s. r. o. - Slovakia

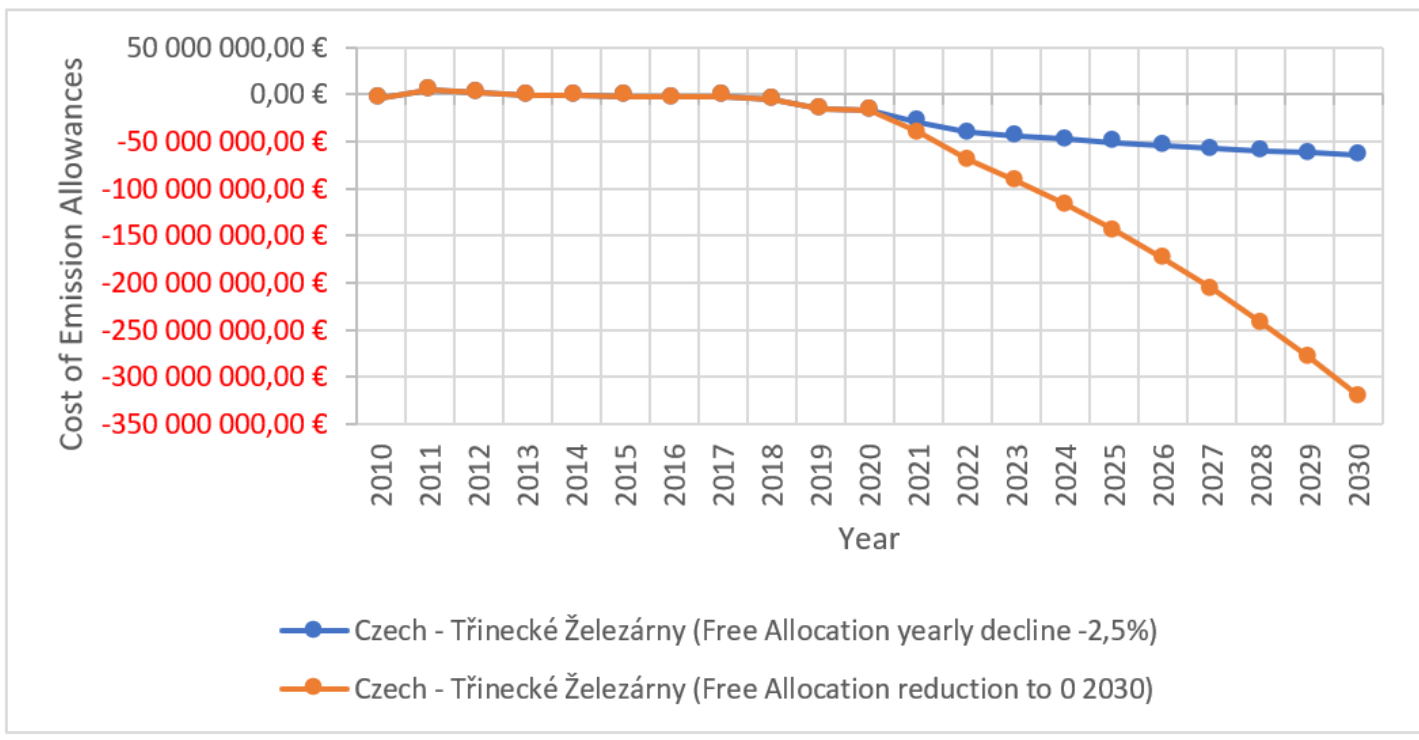

Figure 5 Price of emission allowances including prediction to 2030 - Třinecké Železárny, a. s. - Czech Republic 


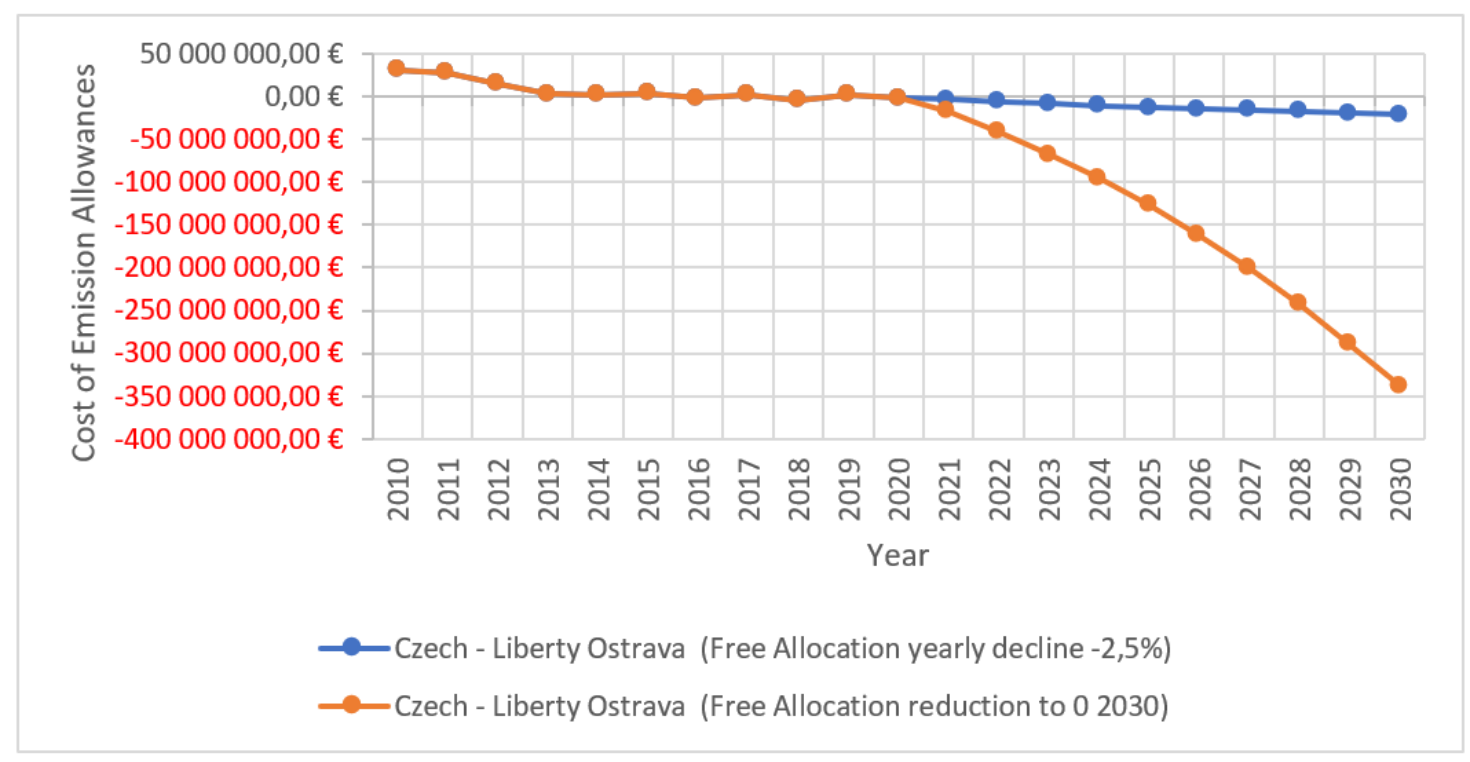

Figure 6 Price of emission allowances including prediction to 2030 - Liberty Ostrava - Czech Republic

To meet global energy and climate goals, emissions from the steel industry must fall by at least $50 \%$ by 2050 compared to the present situation, with continuing declines towards zero emissions being pursued thereafter. Deep emission reductions are not achievable without innovation in technologies for near-zero emissions steelmaking shown in Figure 7. A sustainable transition for the iron and steel sector will not come about on its own; governments will play a central role [14]. Major and rapid change will be necessary in all cases - and there are clear needs for policies to enable the transition. Far more resources must be devoted to accelerating innovation on several fronts. Credible new policy solutions are needed to make it viable to pursue low- $\mathrm{CO}_{2}$ production routes that are up to $20 \%$ more expensive than current routes [8]. To remain competitive steel companies in Slovakia and the Czech Republic need a strategy until 2050 as soon as possible to achieve near-zero emission production of steel.

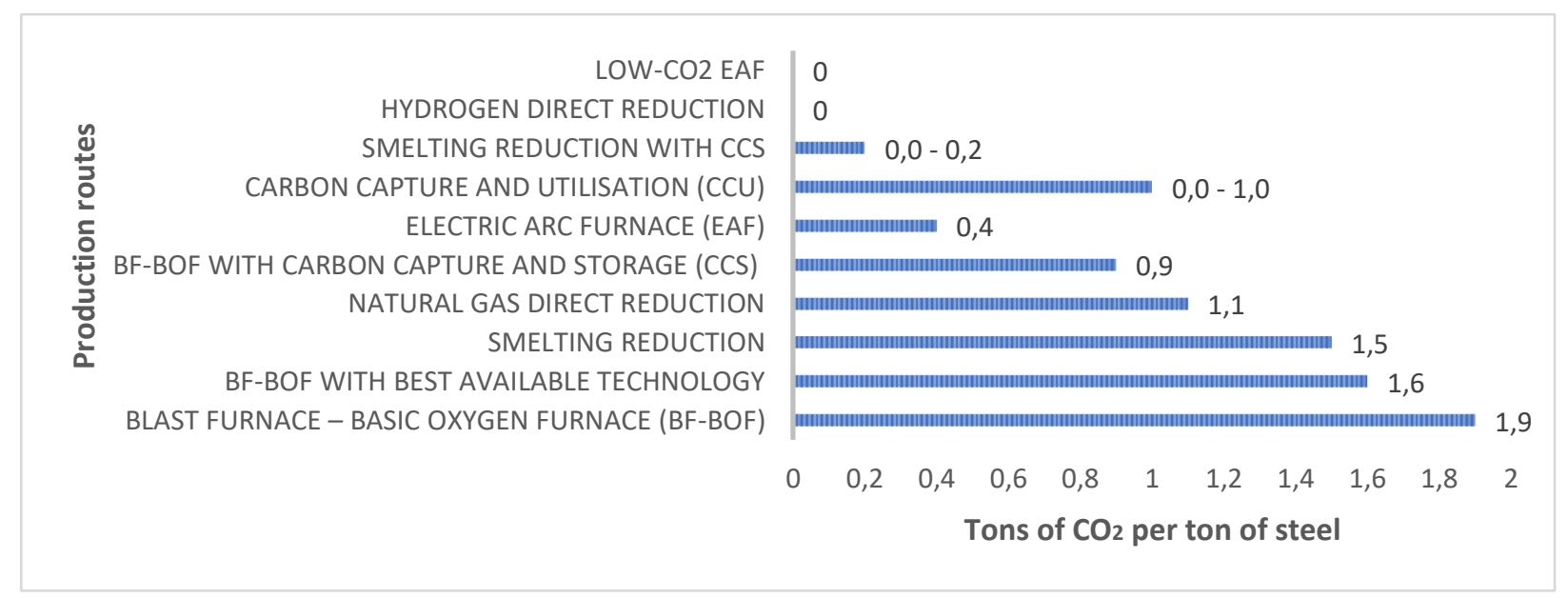

Figure $7 \mathrm{CO}_{2}$ - Intensity of EU steel production processes - tons of $\mathrm{CO}_{2}$ per ton of steel [8]

\section{CONCLUSION}

Europe's ambitious plan to achieve carbon neutrality by 2050 is a major challenge for the metallurgical industry. Individual metallurgical companies must make great efforts to achieve the highest possible reduction in $\mathrm{CO}_{2}$ emissions despite potential technological, organizational, regulatory, and financial barriers. The rising price of 
emission allowances in the coming years and the potential reduction of free allowances with the arrival of CBAM can cause for steel producers an increase in the production price by more than $100 €$ per ton of steel produced by 2030 , which may lead to reduced competitiveness of Slovak and Czech steelworks. However, through innovation, low-carbon technology deployment and resource efficiency, iron and steel producers have a major opportunity to reduce energy consumption and greenhouse gas emissions, develop more sustainable products and enhance their competitiveness. However, financial assistance from the government and the European Union will be needed in this regard.

\section{ACKNOWLEDGEMENTS}

\section{Authors are grateful for funding by VEGA project 1/0212/21.}

\section{REFERENCES}

[1] Paris Agreement - Parížska dohoda o zmene klímy. [online]. 2021. [viewed: 2020-06-26]. Available from: https://www.consilium.europa.eu/sk/policies/climate-change/paris-agreement/.

[2] A European Green Deal. [online]. 2021. [viewed: 2020-06-26]. Available from: https://ec.europa.eu/info/strategy/priorities-2019-2024/european-green-deal.

[3] 2030 climate \& energy framework. [online]. 2021. [viewed: 2020-06-26]. Available from: https://ec.europa.eu/clima/policies/strategies/2030 en.

[4] EU Emissions Trading System (EU ETS). [online]. 2021. [viewed: 2020-06-26]. Available from: https://ec.europa.eu/clima/policies/ets en.

[5] The Role of Industrial Emissions Within the EU: Trends and Policy. [online]. 2021. [viewed: 2020-06-26]. Available from: https://climatepolicyinfohub.eu/role-industrial-emissions-within-eu-trends-and-policy.

[6] How are emissions of greenhouse gases by the EU evolving?. [online]. 2021. [viewed: 2020-06-26]. Available from: https://ec.europa.eu/eurostat/cache/infographs/energy/bloc-4a.html.

[7] Steel's contribution to a low carbon future, Worldsteel Association. [online]. 2021. [viewed: 2020-06-26]. Available from: https://www.worldsteel.org/en/dam/jcr:c3acc5fd-e3c2-458c-a2cc8c4880b9334c/Steel\%2527s+contribution+to+a+low+carbon+future.pdf.

[8] Industrial Transformation 2050, Material Economics. [online]. 2021. [viewed: 2020-06-26]. Available from: https://materialeconomics.com/publications/industrial-transformation-2050.

[9] Slovakia: $\mathrm{CO}_{2}$ Country Profile. [online]. 2021. [viewed: 2020-06-26]. Available from: https://ourworldindata.org/co2/country/slovakia.

[10] Czechia: $\mathrm{CO}_{2}$ Country Profile. [online]. 2021. [viewed: 2020-06-26]. Available from: https://ourworldindata.org/co2/country/czech-republic.

[11] EU's carbon border tariff to target steel, cement, power, EURACTIV. [online]. 2021. [viewed: 2020-06-27]. Available from: https://www.euractiv.com/section/energy-environment/news/eus-carbon-border-tariff-to-targetsteel-cement-power/.

[12] The Green Brief: CBAM enters with a bang, EURACTIV. [online]. 2021. [viewed: 2020-06-27]. Available from: https://www.euractiv.com/section/energy-environment/news/the-green-brief-cbam-enters-with-a-bang/.

[13] EU Parliament votes to retain free CO2 quotas for industry, EURACTIV. [online]. 2021. [viewed: 2020-06-27]. Available from: https://www.euractiv.com/section/energy-environment/news/eu-parliament-votes-to-retain-co2quotas-for-industry/.

[14] Iron and Steel Technology Roadmap - Towards more sustainable steelmaking, IEA. [online]. 2021. [viewed: 2020-06-27]. Available from: https://www.iea.org/reports/iron-and-steel-technology-roadmap. 